\title{
KECEMASAN IBU DI MASA PANDEMIK COVID-19 TERHADAP DUKUNGAN KEPATUHAN KUNJUNGAN IMUNISASI DASAR PADA BAYI DI DI PUSKESMAS BALEREJO KABUPATEN MADIUN
}

\author{
Mertisa Dwi Klevina $^{1)}$, Yeni Utami ${ }^{2}$ \\ ${ }^{1,2}$ Program Studi Kebidanan STIKes Bhakti Husada Mulia Madiun \\ Email: mer_tisa@yahoo.co.id
}

\begin{abstract}
ABSTRAK
Imunisasi pada balita yaitu sebuah program imunisasi yang telah diwajibkan oleh pemerintah guna mencegah penyakit hepatitis, poliomyelitis, difteri, TBC dan campak. Selama masa pandemi Covid-19 mengakibatkan program imunisasi terkendala, seperti jadwal imunisasi tidak berjalan dengan baik karena adanya penutupan tempat pelayanan imunisasi. Peneliti menganalisis faktor yang berhubungan dengan kepatuhan dalam kelengkapan imunisasi dasar pada bayi di masa pandemi Covid19.

Jenis penelitian ini yaitu analitik observasional dengan pendekatan cross sectional. Populasi dalam penelitian ini ibu yang mempunyai anak usia 0-12 bulan yang diambil dengan simple random sampling dengan sampel 72 responden. Variabel dalam penelitian ini yaitu pengetahuan, kecemasan dampak Covid-19, persepsi, dukungan keluarga dan dukungan pelayanan imunisasi. Alat ukur yang digunakan berupa kuesioner yang telah diuji validitas oleh peneliti. Uji yang digunakan uji chi square.

Dari hasil penelitian didapatkan bahwa variabel yang berhubungan dengan kepatuhan imunisasi dasar), Kecemasan dampak Covid-19 ( $\mathrm{p}$ value $=0,001)$, dukungan keluarga ( $\mathrm{p}$ value $=0,004)$, dan dukungan pelayanan imunisasi ( $\mathrm{p}$ value $=0,002$ ). Sedangkan variabel yang tidak berhubungan dengan kepatuhan imunisasi dasar adalah persepsi $(\mathrm{p}$ value $=0,145)$.

Hasil penelitian tentang kepatuhan dalam kelengkapan imunisasi dasar menunjukkan bahwa sebagian besar responden patuh dalam kelengkapan imunisasi, yaitu sebanyak 57 responden $(79,8 \%)$ dari total 72 responden. Diharapkan program imunisasi tetap patuh dilaksanakan guna meningkatkan kekebalan tubuh bayi terlebih pada masa pandemi Covid-19. Selain itu diharapkan ibu tetap melakukan kunjungan ke posyandu untuk memantau tumbuh kembang anak.
\end{abstract}

Kata kunci: Imunisasi dasar, kecemasan,Kepatuhan

\section{ABSTRACT}

Immunization for toddlers is an immunization program that has been required by the government to prevent hepatitis, poliomyelitis, diphtheria, tuberculosis and measles. During the Covid19 pandemic, the immunization program was hampered, such as the immunization schedule did not go well due to the closure of immunization service centers. Researchers analyzed factors related to compliance in the completeness of basic immunization in infants during the Covid-19 pandemic.

The type of this research is observational analytic with cross sectional approach. The population in this study were mothers who had children aged 0-12 months who were taken by simple random sampling with a sample of 72 respondents. The variables in this study were knowledge, anxiety about the impact of Covid-19, perception, family support and support for immunization services. The measuring instrument used is a questionnaire that has been tested for validity by the researcher. The test used is the chi square test.

From the results of the study, it was found that the variables related to basic immunization compliance), Covid-19 impact anxiety ( $p$ value $=0.001)$, family support ( $p$ value $=0.004)$, and immunization service support ( $p$ value $=0.002$ ). While the variable that is not related to basic immunization compliance is perception ( $p$ value $=0.145$ ).

The results of the study on compliance with the completeness of basic immunization showed that most of the respondents complied with the completeness of immunization, as many as 57 respondents (79.8\%) out of a total of 72 respondents. It is hoped that the immunization program will remain obedient 
in order to increase the baby's immune system, especially during the Covid-19 pandemic. In addition, mothers are expected to continue to make visits to the posyandu to monitor the child's growth and development.

Keywords: basic immunization, anxiety, compliance

\section{PENDAHULUAN}

Apalagi pada masa pandemi Coronavirus disease 2019 (Covid-19) Utami (2020) dalam jurnal Anggraini \& Agustin (2020) mengeluarkan pendapat bahwa ada hal yang menjadi sorotan selama masa pandemi Covid-19 yaitu salah satunya risiko masalah kesehatan pada anak. Karena, puskesmas dan posyandu banyak yang menutup layanan imunisasi untuk balita selama saat masa pandemi Covid-19. Hal tersebut mengakibatkan jangkauan imunisasi dasar untuk balita menjadi lebih kecil lagi.

Imunsasi dasar pada bayi dilaksanakan saat bayi usia 0 sampai 12 bulan. Program imunisasi nasional di indonesia dilaksanakan oleh Kementerian Kesehatan sejak tahun 1977. Menurut Kemenkes (2018) data riset Kesehatan Dasar tahun 2018 menunjukkan cakupan imunisasi dasar lengkap (IDL) mencapai $57,9 \%$, imunisasi dasar tidak lengkap sebesar 32,9\% dan 9,2\% tidak diimunisasi. Sedangkan menurut Dinas Kesehatan wilayah Jatim pada 2013 disebutkan angka yang masih tinggi dengan kejadian penyakit yang seharusnya mampu diatasi dengan sebuah imunisasi. Peningkatan kasus kejadian difteri yang semakin menunjukkan angka yang tinggi sebesar sebesar $85,65 \%$ dan campak $1,69 \%$, pertusis sebesar $0,38 \%$ juga hepatitis sebesar 0,19\%. UCI di Jatim pada 2012 mencakup angka imunisasi sebesar $73,02 \%$, menaiknya angka ini sangat melonjak dari tahun 2011.

Dari studi pendahuluan yang diperoleh peneliti yaitu berupa data awal 10 bayi yang didapatkan dari kader posyandu tanggal 12 desember 2020 di Dusun Bayeman Desa Balerejo. Didapatkan bayi 10 bayi dimana dari 7 responden mengatakan bahwa sudah lengkap mengimunisasi anaknya tetapi terdapat jadwal imunisasi yang tidak diberikan sesuai jadwal, dikarenakan pada saat akan diimunisai anak sakit, keluar kota, belum terjadwal imunisasi, ketika bayi dibawa ke tempat pelayanan imunisasi vaksin habis sehingga jadwal imunisasi tertunda, ibu tidak mengetahui informasi terhadap jadwal dibukanya pelayanan imunisasi, dan pelayanan imunisasi yang berkurang sehingga hal tersebut mengakibatkan jadwal imunisasi dari yang seharusnya mengalami kemunduran. 2 diantaranya mengatakan tidak lengkap karena pada saat akan imunisasi posyandu/puskesmas tutup karena PSBB (pembatasan sosial berskala besar) dan cemas karena di masa pandemi takut terhadap penularan Covid-19. Kemudian 1 responden mengatakan tidak imunisasi anaknya karena keyakinan dan faktor kurangnya pengetahuan tentang imunisasi dasar. Jadi terdapat $70 \%$ imunisasi lengkap dan $30 \%$ imunisasi yang tidak lengkap. Berdasarkan data awal yang diperoleh peneliti, penelitian tentang masalah kepatuhan dalam mengimunisasi anaknya membuat peneliti tertarik untuk melakukan penelitian tersebut dan penelitian dilakukan ditempat Desa Balerejo karena peneliti masih menemui terkait masalah yang sudah dijabarkan

\section{METODE}

Penelitian ini menggunakan analitik observasional dengan pendekatan metode crosssectional Teknik yang digunakan dalam penelitian ini yaitu probability sampling yaitu simple random sampling. Dipakai untuk melihat hubungan antara 2 variabel terdiri dari variabel bebas dengan variabel terikat ialah faktor efek dan penyebab dengan memakai uji Chi Square sedangkan untuk kepatuhan memakai uji spearman rank dikarenakan pada uji chi square tidak memenuhi syarat.Peneliti Populasi sasaran dalam penelitian ini adalah seluruh ibu usia 012 bulan di seluruh wilayah kerja Puskesmas Balerejo Kabupaten Madiun. Jumlah ibu yang mempunyai bayi usia 0-12 bulan di wilayah kerja puskesmas Balerejo Kabupaten Madiun sebanyak 309 ibu. keseluruhan sampel yang akan dipakai untuk sekelompok ibu dengan bayi berusia 0-12 bulan di wilayah kerja Puskesmas Balerejo Kabupaten Madiun yaitu 72 responden. 
HASIL

Kecemasan ibu dimasa pandemic Covid 19 terhadap Kepatuhan dalam Kelengkapan Imunisasi Dasar pada Bayi di Masa Pandemi Covid-19

Tabel 1

\begin{tabular}{|c|c|c|c|c|c|c|}
\hline \multirow{3}{*}{ Kecemasan } & \multicolumn{4}{|c|}{ Kepatuhan } & \multirow{2}{*}{\multicolumn{2}{|c|}{ Total }} \\
\hline & \multicolumn{2}{|c|}{ Patuh } & \multicolumn{2}{|c|}{ Tidak patuh } & & \\
\hline & $\mathrm{F}$ & $\%$ & $\mathrm{~F}$ & $\%$ & $\mathrm{f}$ & $\%$ \\
\hline Cemas & 55 & $85.9 \%$ & 9 & $14.1 \%$ & 64 & $100 \%$ \\
\hline Tidak cemas & 2 & $25.0 \%$ & 6 & $75.0 \%$ & 8 & $100 \%$ \\
\hline Jumlah & 57 & $79.2 \%$ & 15 & $20.8 \%$ & 72 & $100 \%$ \\
\hline
\end{tabular}

Berdasarkan tabel di atas, diketahui bahwa dari 72 responden pada status patuh imunisasi, 55 responden $(85,9 \%)$ mengalami cemas dan yang tidak cemas sebanyak 2 responden $(25,0 \%)$. Dari 72 responden pada status tidak patuh imunisasi, 9 responden $(14,1 \%)$ mengalami cemas dan 6 responden $(75,0 \%)$ tidak cemas.Hasil analisis yang diperoleh dari uji fisher menunjukkan bahwa nilai $p$ value $0,001(<\alpha=0,05)$, sehingga $\mathrm{Ha}$ diterima, yang artinya ada hubungan antara kecemasan dampak Covid-19 dengan kepatuhan dalam kelengkapan imunisasi dasar pada bayi di masa Pandemi Covid-19 di Puskesmas Balerejo Kabupaten Madiun.

\section{PEMBAHASAN}

Dari hasi penelitian menunjukkan bahwa sebagian besar responden yang merasa cemas namun mereka patuh terhadap imunisasi yaitu sebanyak 55 responden $(85,9 \%)$, ini didukung dari jawaban responden. Sebagian besar responden memilih jawaban yang menekankan pada rasa khawatir ibu ketika membawa anak untuk imunisasi tetapi berusaha menyakinkan diri tidak terpapar coronavirus karena telah mematuhi protokol kesehatan dengan total 287 jawaban pada pernyataan kuesioner. Pada hasil analisis dengan uji Fisher, diperoleh $p$ value $=0,001$ ( $p$ value $<0,05)$. Berdasarkan uji tersebut menunjukkan ada hubungan antara kecemasan dampak dari Covid19 dengan kepatuhan dalam kelengkapan imunisasi dasar pada bayi di Masa Pandemi Covid-19 di Puskesmas Balerejo Kabupaten Madiun.

Menurut Supriyono mendefinisikan kecemasan adalah reaksi dari rasa takut terhadap atau didalam suatu situasi. Secara lebih jelas singer mengatakan bahwa kecemasan menunjukkan suatu kecenderungan untuk mempersepsikan suatu situasi sebagai ancaman atau stressful (situasi yang menekan). Kondisi yang tiba-tiba muncul membuat masyarakat tidak siap dalam menghadapinya baik secara fisik ataupun secara psikis (Sabir \& Phil, 2016). Menurut Alvara (2020) yang menyimpulkan bahwa selama masa pandemi ini publik akan mengalami kepanikan dan kecemasan yang tinggi dan dengan kecemasan itu akan mempengaruhi perilaku publik khususnya adalah perilaku yang berhubungan dengan kesehatan, ada beberapa perilaku kesehatan yang meningkat seperti kepatuhan terhadap protokol kesehatan 3M memakai masker, mencuci tangan, berolahraga dan jaga jarak tetapi ada juga beberapa perilaku kesehatan yang menurun yaitu seperti takut untuk ke pelayanan kesehatan, takut untuk berobat ataupun takut untuk keluar rumah, dengan memetuhi protokol kesehatan maka resiko penularan Covid-19 akan menurun. Menurut Sari (2015) menyatakan bahwa semakin tinggi tingkat kecemasan seseorang tentang sesuatu maka tingkat kepatuhannya akan semakin tinggi.

Penelitian ini sejenis dengan penelitian yang dilakukan oleh Sri Sumarni di desa Banjar Barat Kecamatan Gapura pada tahun 2019 dengan hasil uji statistik $p$ value $0,000<0,05$ dan tingkat kepercayaan 95\%, maka dapat disimpulkan bahwa terdapat hubungan yang signifikan antara kecemasan ibu dengan pemberian imunisasi pada bayi usia $0-12$ bulan di Desa Banjar Barat.

Menurut peneliti pada tabel didapatkan hasil penelitian bahwa ibu yang cemas sebanyak 64 responden dengan kepatuhan terhadap imunisasi yaitu 55 responden. Kecemasan responden akibat pandemi Covid-19 mempengaruhi kepatuhan ibu terhadap 
imunisasi. Dimana semakin tinggi ibu yang cemas maka akan semakin tinggi tingkat kepatuhan ibu. Hal ini ditunjukkan dengan pernyataan kuesioner nomor 10 yang berbunyi "Saya khawatir ketika membawa anak saya untuk imunisasi tetapi saya berusaha menyakinkan diri tidak akan terpapar coronavirus karena telah mematuhi protokol kesehatan". Untuk kecemasan ibu berupa rasa khawatir dikarenakan cemas yang dialami ibu dianggap sebagai akibat dari stress yang mempengaruhi tingkah laku. Sedangkan ibu yang cemas namun tidak patuh sebanyak 6 responden, hal ini kemungkinan disebabkan dari dampak pandemi Covid-19 yang mengakibatkan sebagian responden tidak membawa bayinya untuk imunisasi dikarenakan posyandu tutup selama pandemi dan takut membawa anak imunisasi di rumah sakit, yang didukung dari pernyataan kuesioner. Maka dari itu ibu diharapkan dapat menerapkan protokol kesehatan dan mematuhi imunisasi dengan menyakinkan diri tidak terpapar Coronavirus ditempat pelayanan imunisasi, untuk tetap memberikan imunisasi lengkap kepada bayinya

\section{SIMPULAN DAN SARAN \\ Simpulan}

Hasil penelitian menunjukkan Ada hubungan yang signifikan antara kecemasan dampak dari Covid-19 dengan kepatuhan dalam kelengkapan imunisasi dasar pada bayi di masa pandemi Covid-19

\section{Saran}

Peneliti mengharapkan adanya penelitian lebih lanjut untuk mendapatkan informasi yang lebih mendalam mengenai faktor-faktor yang berhubungan dengan kepatuhan dalam kelengkapan imunisasi dasar pada bayi di masa pandemi Covid-19 dengan jenis penelitian, metode dan sampel yang berbeda dan lebih besar.

\section{DAFTAR PUSTAKA}

Aliansy, D., \& Hafizurrachman. (2016). Pengaruh Penatalaksanaan Program Imunisasi Oleh Bidan Desa, Kepatuhan Standar Operasional Prosedur, Dan Ketiersediaan Sarana Prasarana Terhadap Efiksasi Imunisasi Dasar Di Kabupaten Cianjur Tahun 2014. Jurnal Bidan,

Alipour, A., Ghadami, A., Farsham, A., \& Dorri, N. (2020). A New Self-Reported Assessment Measure For Covid-19 Anxiety Scale (Cdas) In Iran: A WebBased Study. Iranian Journal Of Public Health, 49 (7), 1316.

Anggraini, Y., \& Agustin, K. (2020). Efektivitas Pengetahuan Orangtua Batita Terhadap Ketepatan Imunisasi Dasar Dan Booster Pada Masa Pandemi Covid-19 Di Posyandu Wilayah Kerja Puskesmas Colomadu. Jurnal Ilmiah Maternal, 4(2).

Aritonang, J., Anita, S., Sinarsi, \& Siregar, W. W. (2020). Kecemasan Pandemi Covid19 Dalam Keikutsertaan Posyandu Di Kelurahan Pekan Tanjung Morawa Tahun 2020. Jurnal Reproduction Health (1-6), 5. Fakultas Farmasi dan Ilmu Kesehatan: Universitas Sari Mutiara Indonesia

Kementrian Kesehatan Republik Indonesia \& Unicef Indonesia. (2020, Agustus). Imunisasi Rutin Pada Anak Selama Pandemi Covid-19 Di Indonesia: Persepsi Orang Tua Dan Pengasuh. 